\section{Plant Physiology}

By Prof. Nicolai A. Maximov. Edited by R. B. Harvey and A. E. Murneek. (McGraw-Hill Publications in the Botanical Sciences.) Second English edition, translated and revised from the fifth Russian edition. Translated from the Russian by Dr. Irene V. Krassovsky. Pp. xxii +473 . (New York and London: McGraw-Hill Book Co., Inc., 1938.) 25s.

JICOLAI MAXIMOV is a plant physiologist with I a world-wide reputation, especially in connexion with the water and soil relations of the plant, and this alone justifies a translation from the Russian of any work of his, even if it is only a survey of the subject for the benefit of the student. In spite of the fact that there are now several good text-books on plant physiology in English, writzen by British and American authors, one by this well-known Russian, who is an active worker and prolific writer, is bound to bring a certain freshness of outlook, so that it may be regarded as a valuable supplement to any text-book which the student is already using.

This second English edition has been translated from the fifth Russian edition, which was so completely rewritten by Prof. Maximov as to warrant a new title. (The first edition was entitled "Textbook of Plant Physiology".) It should be pointed out, however, that Prof. Maximov's researches are biased towards plants of agricultural importance, and thus this book deals, as he terms it, more with "agrophysiology" than with general plant physiology. Thus the physiology of saprophytes, parasites, bacteria, fungi and algæ is scarcely considered. The book can therefore be strongly recommended as a text-book to students of agriculture and as a supplementary book to students of general botany, since its economic outlook will certainly give added interest to their studies.

The subject-matter is considered in the orthodox manner under such headings as physico-chemical organization and chemical composition of the plant, respiration, growth, photosynthesis, nitrogen assimilation, absorption of mineral elements, water relations, translocation and so forth. Certain subjects such as growth, development and seasonal phenomena receive fuller and better treatment here than in most books on the subject. The book deserves unqualified success.

\section{A Text-Book of Biochemistry:}

for Students of Medicine and Science. By Prof. A. T. Cameron. (Churchill's Empire Series.) Fifth edition. Pp. viii +414. (London: J. and A. Churchill, Ltd., 1938.) 15s.

THE fourth edition of this very successful textbook was reviewed in NATURE of January 6, I934, p. 8. There have been a total of ten editions and reprintings since the original publication of the book ten years ago, so there can be no questioning its utility, especially to medical students, to whom it is primarily addressed.

Any text-book dealing with such a progressive subject as biochemistry is naturally bound to become quickly out of date in parts, so the success of this work is of particular value in offering the author opportunity of revision in the light of recent research. The author has availed himself of the opportunity, with the result that this new edition has been almost completely rewritten. The subject-matter has also been re-arranged. As in the previous edition, the author has assumed a basic knowledge of organic chemistry, but justifiably opens with a résumé of the concepts of physical chemistry. Thence, the student is brought directly into contact with "biochemical agencies"-enzymes, hormones and vitamins. Here, the subject-matter has been severely curtailed, apparently to satisfy the immediate needs of the medical student. Phytohormones, as such, are dismissed in one sentence, though certain of them, such as indole-acetic acid, indole-propionic acid, skatole, etc., are considered farther on in the book in connexion with the action of intestinal bacteria.

The chapters on the biochemistry of the foodstuffs leave nothing to be desired. We are glad to note that the author has corrected a previous error and here states correctly that strophanthin hydrolyses to glucose, cymarose and strophanthidin.

The rest of the book deals with those branches of biochemistry essential to students of medicine, and concludes with a consideration of pharmacology and of immunochemistry and the chemistry of filterable viruses. The book is a pattern of compression; in fact, to survey such a wide subject in four hundred pages so satisfactorily is a feat of which the author may well be proud.

\section{Icones Plantarum Sinicarum}

Fascicle 5. Edited by Hsen-Hsu Hu and Woon-Young Chun. Pp. iv +50 +plates 201-250. (Peiping: Fan Memorial Institute of Biology, 1937.)

THE publication of fascicle 5 of the "Icones 1 Plantarum Sinicarum" brings the total of plates published in this work to two hundred and fifty. The illustrations are in black and white, most plates include analyses and many show both flowers and fruits. One species is figured on each plate and described in the text in English and Chinese. Nearly all the subjects are woody plants (only five herbs have been figured so far), and the large size of the plates (the work is a folio) is a great advantage in that it allows ample material of the plants to be illustrated. The value of the work is enhanced by the fact that many of the plants figured, especially in fascicles 3-5, are species described in recent years, whilst another valuable feature is the figuring in successive plates of all or most of the Chinese representatives of one genus, as, for example, in Carpinus, Tilia and Deutzia. In the first two fascicles the plates are spoilt, to a large extent, by being too heavily inked, but in fascicles 3-5 they are excellently reproduced from drawings (by C. R. Feng) which are both artistic and botanically accurate. The publication forms a valuable work of reference for students of the flora of China, and it is to be hoped that it will be possible for production to continue, despite the unhappy conditions now prevailing in that country. 